\title{
STRATEJİK İTTİFAK OLUŞUMUNDA TEMEL YETENEKLERİN ÖNEMİ
}

Doç.Dr.Cengiz Demir, Ege Üniversitesi, İktisadi ve İdari Bilimler Fakültesi, İşletme Bölümü, cengiz.demir@ege.edu.tr

Seda Oktay, Ege Üniversitesi, Sosyal Bilimler Enstitüsü, Yönetim Bilimi ve

Organizasyon Yüksek Lisans Program1. sedaoktay85@gmail.com

\section{ÖZET}

Küreselleşme nedeniyle tüm dünya ekonomileri hayatta kalabilmek için farklılık yaratmak zorunda kalmıştır. Bu farklılığı yaratmak ancak ikame edilemeyen ürün ya da hizmetlerle mümkündür. Örgütsel yetenekler, firmaların küresel tek pazarda en önemli değerleridir. Örgütlerin temel yetenekleri, sürdürülebilir rekabet üstünlüğü sağlamak amacıyla stratejik ittifak oluşturmaya zorlamaktadır. İttifak içinde olan örgütler küresel pazarlarda daha çok avantaja sahiptir. Bu çalışmanın amacı, örgütlerin stratejik ittifak oluşturmalarında temel yeteneklerinin önemini vurgulamak ve temel yeteneklerin örgütlere ne gibi katkılar sağlayacağını belirlemektir.

Anahtar Kelimeler: Temel yetenekler, Stratejik İttifaklar

\section{ABSTRACT}

In order to survive, all world economics must have created differences one another because of the globalization. These differences are possible with nonsubstitutable goods and services. Organizational competencies are the key values of companies in the single global market. To provide sustainable competitive advantages, core competencies of organizations force organizations to create strategic alliance. The organizations with strategic alliance have more advantages in the global market. The purpose of this study is to point out the importance of core competencies on the procedures of strategic alliance of organizations and identify the contributions of core competencies on organizations.

Key Words: Core Competencies, Strategic Alliance 


\section{GİRİ̧}

Amerika Birleşik Devletleri (ABD), Japonya ve Avrupa gibi gelişmiş ülkelerin ekonomileri 1960 'lardan bu yana ticaret ve sermaye akışları nedeniyle önemli ölçüde birbirine bağlanmıştır. Küreselleşme olarak tanımlanan bugünkü dönemin en önemli yeniliği dünyanın daha fakir bölgelerinin küresel ticaret, finans ve üretim sistemlerine, sömürge bağımlılı̆ından çok birer ortak ve taraf olarak yer almalarını sağlamasıdır (Çelik,1999). Hızlı bilgi akışı, teknoloji ve sınırların ortadan kalkması gibi faktörler artık pazarları bölgeselden dünya geneline dönüştürmektedir. Yani dünya ortak bir pazar alanıdır. Türkiye'de ise 1980 sonrası döneme dayanan küreselleşme süreci, örgütleri değişime ve bu değişimin getirdiği farklı çözüm arayışlarına zorlamışırı. Bireylerin beklenti ve farklı taleplerini karşılamak adına yapılan üründe ve hizmette farklılık yaratma stratejisi rekabet avantajı yaratmada örgütler için artık yeterli olmamaktadır.

Stratejik ittifaklar örgütlerin yaşamlarını sürdürebilmeleri için alternatif çözüm önerilerinden birisidir. Günümüzde pek çok örgüt stratejik itttifakları maliyetlerini düşürmek veya eksik yönlerini karşılamak amacıyla oluşturmaktadır. Kaynak yaklaşımına göre; stratejik ittifaklarla birlikte İşletmeler kendilerine özgü kaynakları ve dışarıdan elde ettikleri tamamlayıcı kaynaklar sayesinde uzun dönemde rekabet sağlayıcı pozisyonu gerçekleştirebileceklerdir (Harrison ve diğ., 2001). Bu amaç doğrultusunda örgütler kendilerine gerekli olan kaynağı daha az maliyetle bulabilecek ve aralarında kaynak paylaşımı veya değişimi yapabileceklerdir. Stratejik ittifakların örgütler açısından bir diğer yararı da uluslararası pazara girmeyi kolaylaştırmasıdır. Küreselleşme ile oluşan ana ticaret bölgelerine girmek isteyen firmalar o bölge sınırları içinde olan firmalarla işbirliği yaparak sınır engelini aşmaya başlamışlardır. Bu durumda dışarıdaki firmalar "içeridekiler" statüsünü kazanabilmek için içerideki bir firma ile işbirliğine gitmek veya birleşmek gibi yolları seçebilecektir (Keith ve Ruth,1995:219). Kaynak kullanımının kolaylığı, maliyetleri azaltma ve eksiklikleri tamamlama gibi farklılık yaratacak konular örgütün temel yeteneklerine bağlıdır. Bu yüzden günümüzde firmalar sahip oldukları kaynakları başarılı bir şekilde kullanabilmek için temel yeteneklerini ve kabiliyetlerini tam olarak anlamak zorundadır (Bakırtaş ve Bakırtaş,2008).

\section{STRATEJİK İTTİFAK KAVRAMI}

Stratejik ittifak kavramı birden fazla firma arasında oluşan bir anlaşma olup şirket ilişkilerinde veya şirket dışı hareketlerde birlikte hareket etmektir (Wheelen ve Hungar, 2000:127).

Örgütlerin sahip oldukları kaynaklar ve yetenekler rekabet avantajı yakalamada ve hayatlarının devamılı̆̆ını sağlamada büyük öneme sahiptirler. Kaynaklar, temel yetenekler ve örgütü oluşturan herhangi bir unsur açısından veya bu unsurların kullanılmaları açısından zayıf olabilirler. Doz ve Hamel (1998) işletmelerin niçin stratejik ittifak yaptıklarını üç temel başlık altında incelemiştir. Bunlardan birincisi, rakiplerle işbirliği yapmadaki amaç; tek başına 
geliştiremedikleri tamamlayıcı ürün ve hizmetleri dışarıdan elde etmektir. İkincisi; kaynakları ve yetenekleri bir araya getirerek işletmeye ilave değer kazandırmaktır. Sonuncu amaç ise; rakiplerinden yeni yetenekler, beceriler öğrenerek işletmelerine değer katmaktır.

Örneklerden de görüldüğü gibi, işletmelerin tek başlarına ulaşmalarının mümkün olmadığı avantajları veya yararları başka bir işletme ile işbirliği yaparak elde etmeye çalışmaları temel amaçtır. Kısacası, kurulan stratejik ittifaklar eksiklikleri giderme, öğrenen örgüt olma ve kaynak kullanımı açısından önemlidir. Stratejik ittifaklar, işletmelerin sahip oldukları kaynaklar ile onların gelecekteki ihtiyaçları, beklentileri arasındaki boşlukta köprü vazifesi görmektedir (Çakınberk, 2009). Burada önemli olan nokta firmaların bu ittifakı istedikleri amaca ulaşmak için yapmalarıdır.

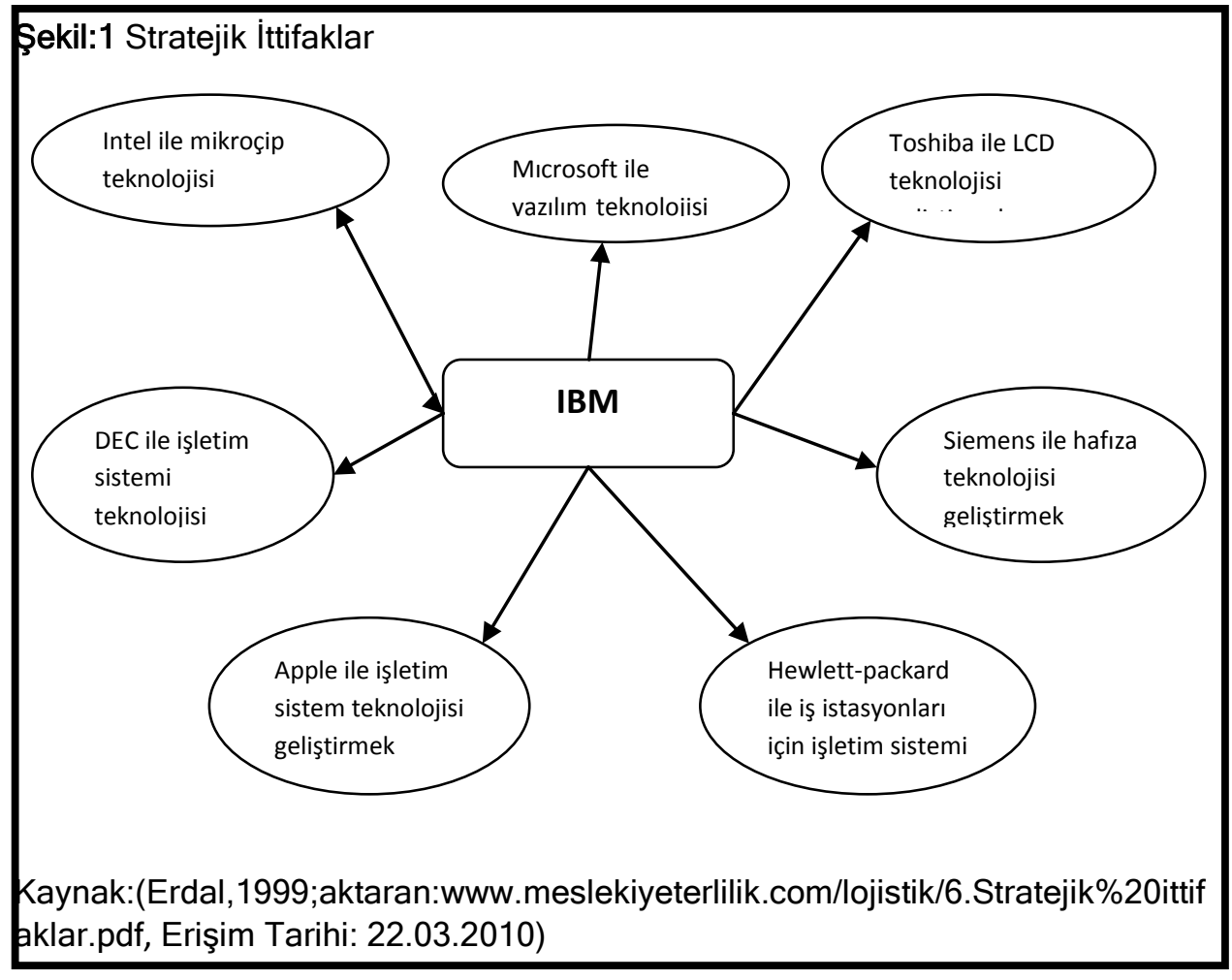

Şekil 1'de IBM'in kurduğu stratejik ittifaklar gösterilmiştir. IBM; İntel, Mıcrosoft, DEC, HP, Siemens, Toshiba ve Apple gibi bilişim markalarıyla oluşturduğu stratejik ittifakları ürün geliştirme alanında kullanmış olup her firma birbirlerinin eksikliklerini tamamlayarak öğrenen örgüt kimliğini gerçekleştirmiştir (Erdal,1999; aktaran:www.meslekiyeterlilik.com/lojistik/6.Stratejik\%20ittifaklar.pd f, Erişim Tarihi: 22.03.2010). Örneğin Toshiba ile IBM LCD teknolojisini 
geliştirirken birlikte hareket etmiş ve intiyaçlar ile kaynaklar ortak bir amaç için birleştirilmiştir.

Birleşmeler iki veya daha fazla firmanın yeni bir firma kurarak bir araya gelmeleri (merger) veya bir firmanın diğer bir firmayı tüm aktif ve pasifleriyle devralması yoluyla (acquisition) gerçekleştirilebilir. Firmaların yeni bir firma kurmaları veya devralmaları söz konusu olunca bir firmanın tüzel kişiliği ortadan kalkar veya hisse payları değişebilir. Stratejik ittifaklarda ise bu söz konusu değildir (Green,1990, aktaran: Çelik, 1999).

Stratejik ittifaklar için en iyi örnek Japon firmalarıdır. Otomobil sanayisinde motor ve vites kutusu geliştirme üzerine endüstriyel işbirlikleri üzerine İtalya'da Honda-Rover ortaklığı kurulmuştur. Bir başka işbirliği örneği Fujitsu ve ICL arasında gerçekleşmiştir. Bu ortaklık pazarlama, teknoloji ve yarı iletken maddeler satın alımı için oluşturulmuş işbirliğidir. ICL, Fujitsu bilgisayarlarını pazarlamaya karşılık Japon gruplarının bilgisayar teknolojilerine öncelikli giriş sağlamaktadır. Bu anlaşma altında ICL de önemli miktarda mikroçip satın almaktadır. Anlaşma, ICL için var olan cılız kaynaklarını ürün sahasını aşmaksızın tamamlama ve yeniden inşa etme fırsatı sunmuştur. (Paliwoda ve Thomas, 1998: 486). Bunların yanında küresel pazarlara ulaşmanın ve rakiplerin önüne geçmenin dağıtım işbirlikleri oluşturmak gibi düşük maliyetli yolları da vardır (Hamel ve Prahalad, 1990). Örneğin; Canon, Kodak markasıyla satılan fotokopi makineleri üretmekte, Samsung'un yaptığı mikro fırınlar GE markasıyla satımaktadır (Enginkaya, 2005). İttifakların örgüt birleşmelerinde olumlu sonuçlarının dışında doğurduğu bir takım zayıf özellikleri de vardır. İlk zayıflık; stratejik ittifakı oluşturan işletmelerden birisinin ittifaka verdiğinden fazlasını almasıdır. İttifaktaki bazı ortaklar diğer ortaklardan daha az bilgi ve teknolojik ilerlemeye sahip olabilir. Belki gelecekte, ittifak yoluyla ortaklardan biri elde edeceği bilgi ve teknolojileri ileride doğrudan rakipleri ile yarışmak için kullanabilir (Wright ve diğ.,1998:102). Bu durumun daha çok rekabetçi ittifaklarda sorun yaratacağı beklenmelidir. Çünkü rekabetçi ittifaklarda öncelik temel stratejik uzmanlığın korunmasıdır. Rakibi ile yapacağı ittifakta işletmenin temel stratejik uzmanlığı rakibi tarafından öğrenildiğinde bunun diğer işletmeye vereceği zarar büyük olabilir (Öge, 2007).

\subsection{Stratejik İttifak Türleri}

Itttifak türleri amaca göre değişiklik göstermektedir (Yoshino ve Rangan 2000, aktaran:Öge2007). Şekil 2; stratejik ittifak türlerini, potansiyel çatışma ve örgütlerin birbirlerini etkileme derecesi ekseninde ele alınmıştır. Bunlar; rekabet öncesi ittifaklar, rekabetçi ittifaklar, rekabet yanlısı ittifaklar ve rekabetçi olmayan ittifaklardır.

Rekabet Öncesi İttifaklar: Ortak faaliyet iyi tanımlanmış olup, işletmeler arasında sınırlı bir etkileşim vardır. Ayrıca rekabet öncesi ittifaklarda ittifak yapan işletmeler ortak ürettikleri ürünleri bağımsız bir şekilde pazarlayabilirler ve ortak 
üretilen ürün işbirliğine giden işletmeler tarafından sadece tek bir konu ile sınırlanmayarak stratejik esneklik sağlayabilirler (Öge 2007).

Rekabetçi İttifaklar: Rekabetçi ittifaklarda en önemli unsur, stratejik uzmanlığın korunmasıdır. Çünkü rekabetçi rekabet karşısında bilgi (enformasyon) akışı zararlı olmaya elverişlidir. Bu tür ittifaklar doğrudan rakipler ile birlikte yoğun bir karşılıklı etkileşim gerektirmektedir. Ortaklaşa $1 \mathrm{MB}$ çip geliştiren Siemens ile Philips, Japonya'da ortaklaşa mikro işlemci üretmeyi planlayan Motorola ve Toshiba ve ABD'de ortaklaşa kamyonet üreten Ford ve Nissan arasındaki ittifaklar örnek olarak verilebilir (Öge,2007). Firmaların bu tip stratejik işbirliğine gitmelerinin birçok nedeni olabilir. Bunlardan en önemlileri ölçek ekonomilerinden yararlanmak, giriş engellerini aşmak, riski azaltmak ve bilgi transferi sağlamak şeklinde sıralanabilir (Çelik 1999).

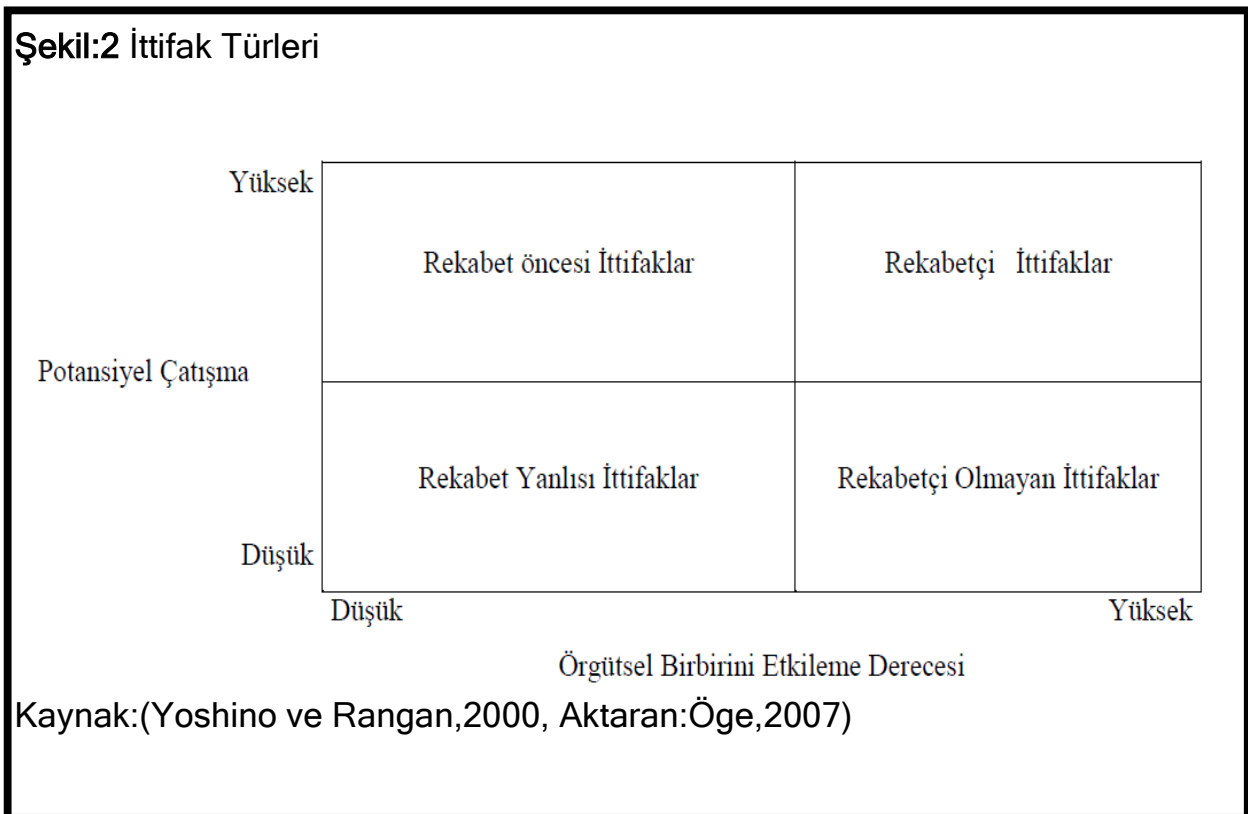

Rekabet Yanlısı Itttifaklar: Dikey ittifaklar gibi üretici ve tedarikçi arasında gerçekleşen ittifaklardır. Bu stratejik ittifak örneğinde Tariş Pamuk Birliği ittifak oluşumunda ittifak ortağını belirleyen taraf olma özelliği taşımaktadır. Bu anlaşma TARiŞ Pamuk Birliği ve üreticileri için en önemli girdi ve maliyet unsuru olan akaryakıtın daha az maliyetle elde edilebilmesi için gerçekleştirilmiştir. İşletme tedarikçisi ile yaptığı bu anlaşma sayesinde hem üreticilerine 7 ay sonra pamuk hasatında pamukla ödemek üzere akaryakıt temin ederek maliyetleri düşürmekte, hem de ödemeleri \% $8,5^{\prime}$ lik indirimle gerçekleştireceği için kendisi için de gelir oluşturmaktadır. İttifakın diğer ortağı olan OPET ise bugünden elinde mevcut olan malın satışını 2 yıllık bir süre için garantilemiş olmaktadır (Karakılıç,2009). 
Firmaların bu tip stratejik işbirliğine gitmelerinin altında yatan nedenlerden en önemlileri, tedarik bağımlıı̆ı̆ndan kurtulmalarının sağlanması ve pazarlama olanaklarının artııııması isteğidir (Çelik,1999).

Rekabetçi Olmayan İttifaklar: Aralarında rekabet olmayan sanayiler arası yapılan birleşmelerdir. Bu tür işbirliği, sıklıkla sabit teknolojili, farklı endüstrilerde mal ve hizmetlerin üretimini yapan firmalar arasında gerçekleştirilir (Çelik,1999). General Motors'un Isuzu ile yaptığı, her iki işletmenin de satacağı küçük bir otomobil gerçekleştirmek için yaptıkları ortaklığı örnek olarak verebiliriz. Bu tür işbirliğinde karşılıklı etkileşim yüksektir. Çünkü yeni bir otomobilin ortaklaşa geliştirilmesi farklı seviyelerde ve çeşitli işletme fonksiyonlarında (imalat, pazarlama, mühendislik, tasarım gibi) yakın temas gerektirmektedir (Öge,2007).

\section{TEMEL YETENEK KAVRAMI}

Temel yetenek, bir işletmeyi başka işletmelerden farklı kılan; işletmenin vizyonunu gerçekleştirmesinde temel rol oynayan, rakipleri tarafından kolayca taklit edilemeyen bilgi, beceri ve yeteneklerdir. Diğer bir deyişle temel yetenek, işletmeye önemli bir rekabet üstünlüğü sağlayan, işletme için vazgeçilmez nitelikte ve dünya standartlarında olan gizli beceri ve yeteneklerdir (Koçel,2003:298)

Bu tanım ışığında temel yetenek üç faktöre ayrııı. İlki; müşteriler için görülebilir, sektörün değer verdiği, değerli bulduğu nitelikli yetenekleridir. Bu yeteneklerin en önemli özelliği, fırsatlar yakalama ve tehditleri/tehlikeleri ortadan kaldırabilmesidir (Elmacı ve diğ., 2009). İkincisi; emsalsiz ve zor taklit edilebilen olmasıdır. Temel yeteneğin rakipler tarafından taklit edilememesi firma rekabet üstünlüğünün sürdürülebilirliğine olanak sağlamaktadır (Hamal ve Prahalad, 1990). Bir kapasitenin temel yetenek olarak adlandırılabilmesi için, kabiliyet ya da becerinin rekabet açısından benzersiz olması gerekir (Bakırtaş ve Bakırtaş, 2008). Son olarak değişen çevreye uyum sürecidir. Bu süreç iletişim ve bilgi teknolojilerindeki gelişim, işletmeleri küresel rekabete daha duyarlı hale getirmiş̧ir. Bu nedenle işletmeler, tüm genetik kodlarını değişen koşullara göre revize etmek ya da tekrar kodlamak zorundadır (Elmacı ve diğ., 2009). Bu tanım ışığında temel yeteneği, "bir örgütü diğerlerinden ayıran özellikler bütünü" olarak tanımlayabiliriz.

Selznick insanları birbirinden ayıran unsurların onların karakteri olduğunu belirtmiştir. Karakter ise tarihsel bir sürecin ürünüdür ve ait olduğu kişiye özgü özelliklerin toplamını yansıtır. Selznick işletmeleri birbirinden ayıran unsurun da onların karakter özellikleri olduğunu belirtirken, kişisel kavramının işletmelerdeki özdeşini "ayırt edici yetenek" olarak tanımlamıştır (Selznick,1984:42). Bu durumda örgütlerin temel yeteneklerini gündeme getiren unsur rekabet avantajı sağlamak olsa da bunu zorunlu kılan en önemli neden her türlü ürün, teknoloji ve hizmetin taklit edilebilir olmasıdır şeklinde yorumlanabilir. 
Şekil 3'e göre; rekabet avantajlarının kilit unsurları olarak değerlendirilen görünmez kaynaklar, varlıklar ya da yetenekler olarak sınıflandırılabilirler. Görünmez varlıklar, entelektüel mülkiyet hakları, patentler, ticari markalar, telif hakları, kontratlar, ticari sırlar ve veri tabanlarını kapsar (Hall, 1993:608). Ustalık (skills) ya da yetenekler (competencies) ise çalışanların, danışmanların, tedarikçilerin ve dağıtıcıların knowhow'larını kapsamaktadır. Ve örgüt kültürünü yaratan kolektif davranış kalıplarıdır. Görünmez kaynakların sınıflandırılması aşağıda verilmektedir (Hall,1993:609).

\begin{tabular}{|c|}
\hline $\begin{array}{l}\text { Patentler gibi görünmez varlıklarla temsil edilen, sahip olma } \\
\text { kapasitesi }\end{array}$ \\
\hline $\begin{array}{l}\text { Knowhow gibi ustalık ve yeteneklerle temsil edilen yapma } \\
\text { becerileri }\end{array}$ \\
\hline Saygınlık gibi insana bağımlı olan görünmez nitelikler \\
\hline Veri tabanları gibi insandan bağımsız olan görünmez kaynaklar \\
\hline $\begin{array}{l}\text { Ticari markalar gibi yasal olarak korunabilen görünmez } \\
\text { kaynaklar }\end{array}$ \\
\hline $\begin{array}{l}\text { Örgütsel şebekeler gibi yasal olarak korunabilen görünmez } \\
\text { kaynaklar }\end{array}$ \\
\hline $\begin{array}{l}\text { Yasal olarak korunabilen görünmez varlıklar: ticari markalar, } \\
\text { patentler, telif hakları, kontrat ve lisanslar, ticari sırlar, veri } \\
\text { tabanları }\end{array}$ \\
\hline $\begin{array}{l}\text { Yasal olarak korunamayan görünmez varlıklar: kamu alanında } \\
\text { yer alan bilgi, ürün ve şirket saygınlığı, örgütsel ve kişisel }\end{array}$ \\
\hline
\end{tabular}

Buradaki temel amaç, görünür ve görünmez tüm yeteneklerin ayrı ayrı farkında olmak ve stratejilerde doğru yetenek kaynağını kullanabilmektir.

Temel yeteneklerin örgütler tarafından fark edilmesi bu yetenekleri stratejiye dönüştürme sürecinde çok önemlidir. Örgütler kendini tanımayan ve özgüveni olmayan bir bireyden farksızdır. Örneğin; eğer bir yönetici orta büyüklükteki bir işletmedeki temel yetenekleri sayarken 40-50 "yetenek"ten söz ediyorsa, kastettiği, yetenekten çok temel becerileridir (Koçel, 2003: 387- 388). 


\begin{tabular}{|c|c|c|}
\hline \multicolumn{3}{|c|}{ Şekil:3 Temel Yetenekler } \\
\hline İnsana Bağımlı & $\begin{array}{l}\text { Know-How } \\
\text { (Tedarikçilerin, } \\
\text { çalışanların, } \\
\text { dağıtıcıların,reklam } \\
\text { ajanslarının,borsa } \\
\text { simsarlarının) }\end{array}$ & $\begin{array}{l}\text { Öğrenme Becerisi } \\
\text { Kalite Algısı } \\
\text { Değişim Becerisi } \\
\text { Yenilik Yapma Becerisi } \\
\text { Takım Çalışması } \\
\text { Katılımcı Yönelim }\end{array}$ \\
\hline $\begin{array}{l}\text { İnsandan } \\
\text { Bağımsız }\end{array}$ & Veri Tabanı & $\begin{array}{l}\text { Sözleşmeler } \\
\text { Lisanslar } \\
\text { Ticari Sırlar } \\
\text { Entelektüel Mülkiyet Hakları }\end{array}$ \\
\hline Kaynak: (Hall, 1 & 611) & Varlıklar \\
\hline
\end{tabular}

Temel beceri ve kabiliyetleri temel yeteneklerden ayırmak için hazırlanmış olan Şekil 4, yetenek hiyerarşisini anlamakta yardımcı olacaktır. Bu şekilde ayrıca değer yaratma ve belirleme zorlukları da gösterilmektedir. Bu şekil aynı zamanda zorluk derecesi, kabiliyet ve becerilere göre yüksek olan ancak değer yaratma düzeyi de buna bağlı olarak daha yüksek olan yetenekler kategorisini daha alt kategorilere parçalayarak temel yeteneğin diğer yetenek kavramlarından farkını da özetlemektedir (Baker ve diğ.,1997).

Şekil 4'e göre süreç genelden özele doğru inen strateji ve temek yetenekleri ifade eder. Örneğin; herhangi bir alanda yatırım yapılacaksa veya örgüt fiziksel değişikliğe gidecekse örgütün sahip olduğu kaynaklar en az maliyetli ve en verimli stratejiler uygulanmalıdır. Kısacası, kaynakları kullanabilme yeteneği fonksiyonel stratejileri içinde barındııı. Aynı zamanda kabiliyetler fonksiyonel stratejileri uygulamada etkin bir rol oynamaktadır. İs stratejilerine bakıldığında daha çok yetenek kullanımı görülür. Çünkü iş stratejileri diğer örgütlerle rekabet içindeyken farklıık yaratma unsurlarındandır. Şekil 4 ışığında bu modeli buz dağı modeline de benzetebiliriz. Temel yetenekler; daha çok en son kararın verildiği üst yönetim stratejileriyle ilgilidir ve kolay kolay taklit edilmez ve ikamesi yoktur. Çünkü her örgütün yetenekleri birbirinden farklıdır ve karar alma aşamasında temel yetenekler yani buz dağının görünmeyen kısmı devreye girer. 


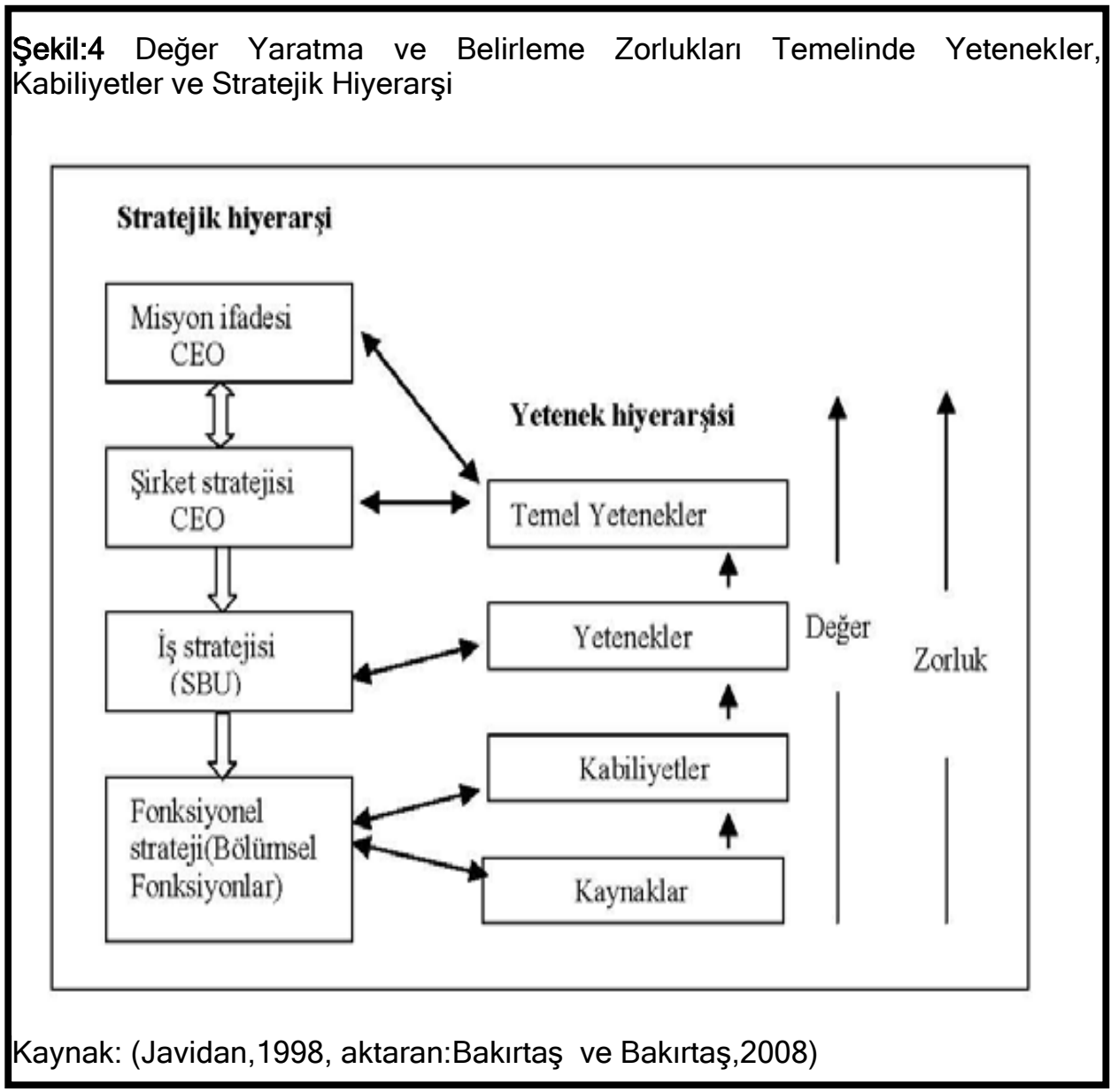

\section{STRATEJİK İTTİFAKLARDA TEMEL YETENEKLERİN YERİ}

Koşullar değişirken sosyal yaşamda olduğu gibi iş yaşamında da yenilikler gereklidir. Yeniliği sağlayabilmek birey bazında kişilik özelliklerine ve kabiliyete bağlıyken örgüt bazında temel yeteneklere ve farkındalığa bağııdır. Temel yetenekleri oluştururken kullandığımı teknoloji bilgisi, stratejiyi gerçekleştirebilme ve uyum sağlama stratejik ittifaklarda da geçerlidir. Stratejik ittifaklar işletmelerin tek başlarına elde edemedikleri gerekli bilgi, sermaye, insan kaynağı, teknoloji gibi kaynaklara stratejik ittifaklar ile sahip olabilmektedirler (Karakılıç,2009). 
Stratejik ittifakları; dalları, meyveleri ve tomurcukları olan büyük bir ağaca, temel yetenekleri de bu ağacın gelişmesini ve meyve vermesini sağlayan minerallere ve yağmura benzetebiliriz (Prahaland ve Hamel,1990). Bunlardan herhangi birinin yokluğunda ağaç büyüyemeyecektir. Bu durumda stratejik ittifakların oluşumunda temel yeteneklerin rolü büyüktür. Bu bağlamda düşünüldüğünde firmanın sürdürülebilir rekabet üstünlüğünü koruması ve geliştirmesinin kaynağı; firma temel yetenekleriyle ilgili olarak yönetimin başarısında, işletmenin teknolojisinde, know-how ve üretim yapabilme becerisidir (Ülgen ve Mirze, 2004). Bu düşünceye ek olarak; firmaların sadece teknoloji ve diğer yeteneklere sahip olması değil, aynı zamanda müşteriler tarafından algılanan değerin ve işletmenin başarılı olmasına yardımcı olan faktörlerin örgütsel öğrenme süreçleri ile entegrasyonu da sürdürülebilir rekabet üstünlüğünü koruma ve geliştirmede önem taşımaktadır (Bakırtaş ve Bakırtaş, 2008). Ayrıca firmaların sürdürülebilir rekabet üstünlüğünü korumada, geliştirmede ve güçlendirmede etkili olan temel yetenekler için gerekli olan unsurlar; i) temel yeteneğin anlamlı bir rekabet avantajı sağlaması, ii) firma ürün çeşitlendirmesi yaparken mevcut işlerin temel yeteneklerinden yararlandığından, yeni işlerin mevcut işlerle benzerlik göstermesi, iii) yeteneklerin taklit edilemez olmasıdır (Prahalad ve Hamel, 1990).

İşletmeler beklentileri doğrultusunda istedikleri kaynak ve yetenekleri kazanabilecekleri ittifakları gerçekleştirmeyi tercih etmektedirler. Bu anlamda temel yetenekler itttifakın oluşum sürecinde ve ortağın seçiminde önemli bir unsur olmaktadır (Karakılıç,2009). Bu seçimler yapılırken örgütlerin amaç birliğine sahip olmaları gerekmektedir. Amaç gerçekleştirme sürecindeki kültürel veya sosyal uyum ittifak sağlanmasında önemli bir kriterdir. Teece ve diğ., (1994) ve Robins ve Wiersema (1995) uyumun, bütünlük içerisindeki şirket yeteneklerinin firmaları rekabet avantajı açısından güçlü kıldığına dikkat çekmişler, paylaşılan yetenekler ve teknik bilgi yüzünden ortaklıkları olan birçok alanda faaliyet gösteren işletmelerin yüksek performans gösterdiklerini bulmuşlardır (Eren ve diğ., 2005). Bunun aksine Bleeke ve Ernst'e göre benzer temel yeteneklere sahip rakipler arasında yapılan ittifaklar ortakların gerilimleri nedeniyle başarısız olabilmektedir. Ancak bu sayede aynı zamanda kendi sektöründe faaliyet gösteren bir başka işletme ile ittifak gerçekleştirme ile işletme yeni ürün ve teknolojilere ulaşabilmekte, ürün ve teknolojiye yapılan yatırımları azaltma imkanı elde etmektedir (Karakılıç,2009).

Stratejik ittifakı temel yeteneklerle oluşturmak, dışarıdan gelecek tehditlere ve rakiplere karşı uzun veya kısa dönemli olarak en kullanışı yöntemdir (Morrow, 1991).

\section{SONUÇ}

Pazarların küreselleşmesi ve yeni yönetim anlayışlarının gelişmesi üzerine önem kazanan örgütlerin temel yetenekleri kavramları, pazardaki pek çok örgütü etkisiz hale getirmek ve eksiklikleri gidermek adına kullanılan bir yöntemdir. Temel yeteneklerin farkında olmak sadece rekabet avantajı yaratmayacak aynı 
zamanda örgütlerin kendilerini geliştirmelerinde ve tedarikçileri ile olumlu ilişkiler kurmalarına da yararlı olacak bir kavramdır.

Kısacası, bir örgütün zamana, değişime ve değişimle birlikte gelen yok olma intimaline direnebilmesi için gerekli olan, yeteneklerinin farkında olmaktır. Başka bir deyişle amaç; temel yetenekleri kullanarak ortak pazarda daha iyi bir yer edinmek, rekabetten karlı çıkabilmek ve rakiplere karşı üstünlük sağlamaktır. Teknoloji, bilgi ve iletişim yönetimi her ne kadar fark yaratmanın temel unsurları olsa da artık taklit edilebilir ve her zaman ikamesi olan kavramlardır. Bu yüzden nadirlik kelimesini örgütler için kullanırken artık temel yeteneklerden bahsedilmesi gerekmektedir. Bu bağlamda düşünüldüğünde örgütlerin rekabetten karlı çıkabilmeleri ve bu karlıı̆ı devam ettirebilmeleri için sahip oldukları bilgi, teknoloji ve becerileri temel yeteneklerle birleştirilmelidirler.

Bireylerin kişilik özellikleri nası ki onların sosyal yaşantılarını belirliyorsa örgütlerin kişiliğini de onların kültürleri ve bu kültürle birlikte gelen yetenekleri oluşturmaktadır. Temel yetenek kavramı "örgütlerin kendisinin farkında olmasının yanı sıra eksikliklerini de görmesi" anlamına da gelir. Eksiklikler ise, iç ve dış çevreden giderilmek zorundadır. Bir örgüt kendi iç çevresinde bu eksikliğini gideremiyorsa dış çevresinden yardım alacaktır veya ortaklığa gidecektir. İttifak kavramı da bu süreç içinde yerini alır. Oluşturulan ittifaklar örgütlerin temel yeteneklerinin birbirlerini tamamlamalarıla başarıya ulaşır. Yaratılan sinerji ve diğer örgütlere karşı yaratılmış olan fark kurulan ittifakı amaçlanana ulaştırmaktadır.

Örgütlerin diğer örgütlerle stratejik ittifak yapmalarının en önemli nedeni; tek başlarına geliştiremedikleri ikame ürün ve hizmetleri elde etmektir. Ardından da kaynaklarını ve yeteneklerini bir araya getirerek örgütün ihtiyacı olan becerileri öğrenmek olduğu bilinmektedir.

Temel yeteneklerle oluşturulmuş stratejik ittifaklar kaynakların daha verimli ve ortak kullanımını sağlamaktadır. Diğer bir anlatımla birbirini tamamlayan iki farklı temel yeteneğe sahip örgütler bir amaç için güçlerini süreli olarak birleştirirler.

Örgütlerin görünen (fiziksel) ve görünmeyen (sosyal) yetenekleri oluşturdukları stratejik ittifaklarla gün yüzüne çıkar. İttifaklarda her ikisinin kullanılması da mümkün olup ulaşılacak hedefe göre yetenek stratejisi belirlenir. Belirlenmiş stratejiyi uygularken de hangi örgütün hangi yeteneğiyle katkı sağlayacağı göz önünde bulundurulur.

İttifaklar yapılırken dikkat edilmesi gereken önemli konular göz ardı edilmemelidir. İttifak oluşturulacak örgütler analiz edilmeli ve çok iyi tanınmalıdır. Her iki örgütün de kültürlerinin, amaçlarının, yetenek farklılık veya benzerliklerinin farkında olmaları gerekmektedir. Bu durumda yapılacak ittifakın türünün de önemi büyüktür. İttifak yapılacak örgütün seçiminde, amaçlara en uygun olanını karşılayacak şekilde ittifak türünün seçilmesine dikkat edilmelidir. 
Sonuç olarak; örgütlerde nadir olan, taklit edilemeyen ve ikamesi olmayan unsurlar olarak tanımlanan temel yetenekler stratejik ittifak oluşumunda büyük önem taşımaktadır. Bu yeteneklerin de kurulan ittifaklarda birbirini tamamlıyor olması ve doğru şekilde kullanılması verimi artıracak ve örgütleri istenen amaca ulaştıracaktır.

\section{KAYNAKÇA}

Baker J. C., Maps J., New C. C.,Szwejzevski M. (1997). "A Hierarchical Model of Business Competence," Integrated Manufacturing Systems, 8 (5):265-272.

Bakırtaş i., Bakırtaş H. (2008). "Firmaların Sürdürülebilir Rekabet Üstünlügünün Bir Kaynağı Olarak Temel Yetenek: Genel Bir Değerlendirme," Selçuk Üniversitesi, Sosyal Bilimler Dergisi, 19:101-119.

Bülbül Y. (2000). Stratejik İttifaklar: Küreselleşmeye Müteşebbis Yaklaşım, Alfa Basım Yayın Dağ., 1. Baskı, İstanbul.

Çakınberk A. (2009). "Stratejik Itttifak Anlaşmaları: Türk Işletmeleri Üzerine Bir Değerlendirme," E-Journal of New World Sciences Academy, 4(2):170-179.

Çelik O. (1999). "Küreselleşme Sürecinde Firmalar Arası Stratejik İşbirliği," Ankara Üniversitesi, Siyasal Bilgiler Fakültesi Dergisi, 14(1): 24-39.

Elmacı O., Sevim Ş., Çelikkol H. (2009). "Işletme Stratejilerinin Eyleme Dönüstürülmesinde Strateji Haritası ve Kurumsal Karne (BSC)'nin Oluşturulmasına Yönelik bir Uygulama," Journal of Azerbaijani Studies, 12(2): 90-109.

Enginkaya E. (2005). "Japonya'nın Yabancı Pazarlara Giriş Stratejisi," Ege Akademik Bakış Dergisi, 5 (1-2): 99-108.

Erdal M. (1999). "YA/EM,Stratejik Itttifaklar: Ortak Seçimi ve Değerlendirilmesi," www.meslekiyeterlilik.com/lojistik/6.Stratejik\%20ittifaklar.pdf, Erişim Tarihi: 22.03.2010.

Eren E., Alpkan L., Erol Y. (2005). "Temel Fonksiyonel Yeteneklerin Firmanın Yenilik ve Finansal Performansına Etkileri," İstanbul Ticaret Üniversitesi, Sosyal Bilimler Dergisi, 4 (7): 201-224.

Hamel G., Prahalad C.K. (1990). "The Core Competence of The Corporation," Harvard Business Review, May-June, :79-90.

Hall R. (1993). A Framework Linking Intangible Resources and Capabilities to Sustainable Competitive Advantag,e Strategic Management Journal,14(8): 608611. 
Harrison S.J., Hitt M.A., Hoskisson R.E., Ireland R.D. (2001). "Resource Complementarity in Business Combinations: Extending to Logic to Organizational Alliances," Journal of Management, 27(6): 679-690.

James D. M. (1991),"Alliances and Assymetry:An Alternative to The Capability Aggregation Model of Alliances." Hoover İnstitution,Stanford University American Journal of Politic Science, 35(4): s:904-933

Javidan, M. (1998). "Core Competence: What Does it Mean in Practice", Long Range Planning, 31 (1): 60-72.

Karakılıç Y.N. (2009). "Stratejik Itttifak Oluşumunda Temel Yeteneklerin Önemi: Tariş Opet Stratejik Ittifakı Balance Scorecard Örneği," Balıkesir Üniversitesi, Sosyal Bilimler Enstitüsü Dergisi, 12 (21): 200-214.

Keith W., Ruth B. (1995). Corporate Financial Strategy, 2.Edition, ButterworthHeinemann İnc., Oxford.

Koçel, T. (2003). İşletme Yöneticiliği, Geliştirilmiş Dokuzuncu Baskı, Beta Basım Yayım AŞ., İstanbul.

Noriaki S.H., Junichi, L. (?). "Inter-firm Relationships in the Telecommunications Industry: Characteristics and Typology," The Department of Industrial Engineering and Management, Tokyo Institute of Technology, 2-121, Ookayama, Meguro-ku, Tokyo 152-8550, JAPAN, pp.1-3.

Öge E. (2007). "Stratejik Ittifaklar," İstanbul Aydın Üniversitesi, Anadolu Bil. Meslek Yüksek Okulu Dergisi, 2(7): 1-21.

Paliwoda J.S., Thomas M.J. (1998). International Marketing, ButterworthHeinemann Inc; Oxford.

Selznick P. (1984). Leadership in Administration, University of California Press, Berkeley.

Ülgen H., Mirze, S. K. (2004). İşletmelerde Stratejik Yönetim, Literatür Yayınları, İstanbul.

Wheelen T.L., Hungar D.J. (2000). Strategic Management and Business Policy, 7nd Edition, Addison-Wesley Publishing Co, Newyork.

Wright P.L., Kroll M.J., Parnell J.A. (1998). Strategic Management, Perentice Hall,Upper Saddle River, Fourth Edition, New Jersey. 